\title{
History and Status Quo of the Mongolian Nadamu
}

\author{
Wanhu Li \\ Institute of physical education \\ Yangtze University \\ Jingzhou, Hubei. China \\ 912074724@qq.com
}

\begin{abstract}
Analysis through the historical literature, logical induction, basis on the formation and development of Mongolian Nadamu, expounds the history classics and early study on the three games, the evaluation and development of Nadamu, modern social life and related research on Nadamu, Results indicates: under the environment of national cultural construction, the cultural development and innovative research will be conducted into depth continuously, with the strong support from the national policies and help, the national non-material cultural heritage such as Nadamu, Aobao Festival, Bock and Mongolian Chess, will have a better space for development, constantly adapt to the social development of the times, and add brilliant colors to the prosperity of China's traditional culture.
\end{abstract}

Keywords- Nadamu; Mongolian; history; status

\section{INTRODUCTION}

In June 2006, the Mongolian Nadamu was inscribed on the list of the first national non-material cultural heritage, which was a milestone in the development history of Nadamu. As a national non-material cultural heritage, the significance and value for research and conservation is self-evident. In the long course of historical development and evolution, Nadamu merged with Mongolian traditional sports, religion, clothing, food, dance, poetry and athletics. It has been an important cultural festival accompanied by the Mongolian nationality. However, due to the impact of today's economic and cultural development of globalization, Nadamu, like other traditional forms of culture, is facing with the crisis of being marginalized. In order to better preserve and develop this national important non-material cultural heritage in the new era, a number of experts, scholars and staff have put a lot of efforts over the past years and made a huge contribution. This paper aims to show the early development and research results and find some routine characteristics of non-material cultural heritage preservation and protection for their future development.

Among Mongolian herdsmen, Nadamu is known as the Day, which means entertainment and game. Nadamu is a festival based on traditional Mongolian nomadic culture and primitive religion system. The three games of Bock (also known as Mongolian-style wrestling, which is the national intangible cultural heritage too),horse racing and archery are conducted at Nadamu. Nadamu festival is a folk fair integrated with contests, religious rites and symbols. Over the past many years, all these elements like a cultural mainstream merged into a Nadamu culture. It built the spirit of the Mongolian nationality in the hopes and harmony dreams among people and nature.

\section{THE HISTORY CLASSICS AND EARLY STUDY ON THE THREE GAMES}

There has been a really long history of the three traditional activities, Bock (Mongolian-style wrestling), horse racing and archery since ancient times. In Mongolian epics and folk tales, there are many related legends, for example, the ancient heroes had to win the championship of the three games of men before getting married.

The northern nomadic wrestling activities had an early origin but no early historical records about it. In the section 140 of the book Secret History of the Mongols, that is, the first written works about Mongolia in 1228, or in 1240, it vividly revealed the historical fact that people eliminated dissidents through wrestling. In Duo Sang History of Mongolia, written in French from 1780 through 1852 with four volumes, it recorded that Ogadai (Genghis Khan's son) loved to watch wrestling and also recorded the scene of wrestling between Persian and Mongolian wrestlers. What is more, In "The King Haidu Female Force” of Travels of Marco Polo, it documented a female Aguilar Nepali chose his husband through wrestling and beat all men. Since Yuan Dynasty, wrestling dramas, mainly about hoax horse feast, have been officially recorded. The traditional gathering in the Pulawoerduo has been inherited since Kublai. Every year the noblemen, courtiers Ministers were called together to have a hoax horse feast. In the feast, there were female singing and dancing, and wrestling contests besides grilled lamb meal. The rulers of Yuan Dynasty were fond of Bock (ie wrestling) competition. Unlike the past hoax horse feast, politics was not the focus at gathering in the Yuan Dynasty. The wrestling activities were not just improvised by a King Khan but have become a national routine, which must be held every year. This resulted in the increasing number of court wrestlers so that a special department was established to take charge of wrestlings in 1318. Besides, many poems had been written about the grand feast. For example, Visit Hoax Horse Feast, Visit Shangjing Poetry and Shangjing Poetry. All these are historical records about Bock. The earlier direct evidence about it was the wrestling bronze medal found in the No. 140 tomb in Shaanxi in the 1950s. It displayed Xiongnu wresting according to research.

Horse riding and archery were the survival skills for the nomads under the natural and living environment of the northern. Horse riding and archery had a significant impact on the ancient economics and politics. Therefore people with the 
excellent skills were very favorable. Their names were even be carved to be remembered by later generations. For example, on the Yesongge Monument erected in 1227 (ie: Genghis Khan Monument inscriptions, now kept in the Denktash Museum), it recorded that Genghis Khan's nephew Yesongge archery up to 335 steps away on the triumphant feast for Genghis Khan to host his officers and soldiers after an expedition triumphant return in 1225. The facts show that the horse riding and archery are two skills and trainings accompanied by northern nomadic long and closely related to the economics and military. The record can still be seen in the military section of the book Yi Customs by Mr. Xiao in the Ming Dynasty.

In the Ming Dynasty after Yuan Dynasty, only little information was recorded about Mongolian Three Tournaments. Historical records had gradually increased and more clear by Qing Dynasty. Manchu is another nationality which put emphasis on horse riding and archery. During the reign of Emperor Qianlong, the horse riding and archery were developed for recreation, athletics and performances instead of training and fighting. From the works of art August Mulan Wei, we know that Mongolian princes presented banquet to the emperor, performed Mongolian Songs, sumo, as well as the activities of various skills. It was very similar to the hoax horse feast in the Yuan Dynasty, seemed to be a repeat of the ancient Mongolian hoax horses feast ritual. However, it was not the emperor hosted a banquet to the ministers, but the Mongolian princes presented banquet and performed to Emperor. Many writers had written a lot of lines around that, for example, the long poem Around the Scenery $\cdot$ Sumo by Yi Zhao.

\section{The EVAluAtion AND DEVELOPMENT OF NADAMU}

Mulan Wei (also known as the "Autumn the macaque ceremony") in Qing Dynasty was generally held in May-August. The golden season for the Mongolian was also in May to August when the grasslands looked like being covered with new green clothes. Lots of calves, foals and lambs were born at that season. White milk was like springs. The herders began joyfully to hold activities to welcome the fortunate from this fresh world, such as the annual Aobao Festival (it was the first batch of national intangible cultural heritage), Colt Festival, Playing Horsehair Fair, and Temple Fair. These are the Mongolian traditions inherited since ancient times for gathers and for fun as well. The original Nadamu appeared as one of the entertainment athletic activities at these gatherings, adding more fun and joy to the festivals with different types of performances. It is obvious that the early Nadamu was different from the independent organized, self-contained, perfect Nadamu at present. From some folk records before the $17^{\text {th }}$ century, even if horse racing, wrestling or archery appeared in a variety of events as needed, no records showed that there was an entertainment event with only these three activities together.

Since $18^{\text {th }}$ century, records about the organized event with the three athletics were written in some folk customs. For example, it was writtern in Ba Lin You Qi Log that thousands of monks from 13 temples were gathered at the annual Tempe Fair held at Dabanhui Temple in June since 1730. At the Temple Fairs, both Lamaism grand ceremonies and groups of nationality cultural, sports and commodity exchange activities were held with a crowd of traders and participants. The immediate neighbors Zhaowuda Union also sent some people to participate in the contests of horse running, horse walking, wrestling, archery and chess playing. The source indicates that the temple fair at Daban by Balinyouqi and the temple fair at Ganzhuer Temple (built in 1784) by Hulunbeier are quite well known and enjoy the same reputation. Fortunately, Alxa Customs Log has a more vivid description about the three athletics than the other records, which fully and vividly reflected the grand occasion of Nadamu celebration among early Mongolians.

Qianlong period was the heyday of the Qing Dynasty with social and political stability. The Mongol Prince was familiar with the capital etiquette of meeting the emperor and Mulan Wei ceremony. He also had the power and money to organize grand celebrations. With the historical information about hoax horse feast in Mongolia to follow, a Nadamu event with grand Mongolian Songs and the three athletics was held. That was the complete Nadamu culture mainly with the three athletics in a large scale in the $18^{\text {th }}$ century similar to present event. This was well documented. Unfortunately, no historical information was recorded the popular Nadamu activities in Xilin Gol and Zhaowuda, Mengqi. Generally speaking, the Lamaism culture and folk culture centered with temples have been fully developed since the unified country by Manchu government. The Nadamu culture was also developed and mature at that time.

After a long history of social reforms and historical changes, Nadamu still retained its traditional features. The climax period for Inner Mongolia Nadamu event to develop started from 1947 when the Inner Mongolia Autonomous Region was established. A grand Nadamu festival was held in Hulunbeir Kanjur Temple in 1948.After that, Xilin Gol, Wulanchabu, Yikezhao, Bayannur Leagues all held great Nadamu Festivals. From 1950 to 1953, 16 times large scale Regional Traditional Sports Games had been held. With the help and support of the party and the government, the fi rst Autonomous Region Nadamu Festival was organized in the early 1950s. By 1991, five Nadamu events were held in the regional capital Hohhot. Countless number of local county's Nadamu events had been held. Compared to the previous events, the media publicity about the $5^{\text {th }}$ Autonomous Region Nadamu was more prominent. It was the golden opportunity of China's opening to the outside world. In order to vigorously promote the Inner Mongolia, that was a good opportunity to show off the nationality characteristics of Inner Mongolia. Inner Mongolia Culture published the news about Nadamu Special Serial. Inner Mongolia Daily continuously published a lengthy History of Nadamu from May 18 through June 27 of that year to describe the important historical facts of relevant Nadamu culture.

\section{NADAMU IN MODERN SOCIAL LIFE AND RELATED RESEARCH}

Today, Nadamu event is no longer just the traditional Mongolian sports, cultural and entertainment event. It has turned to be a carrier centered with sports culture to promote economic and tourism resource development, and promote the culture of prairie. Based on the traditional programs, some of 
the modern sports, such as judo, motorcycle, motor racing, soccer ball, and basketball, have been added to the modern Nadamu. In the Winter Nadamu held in Hulunbeier, the eastern part of Inner Mongolia, the programs include snow bock, snow horse riding, dressage horses, hockey, camels pulled sledge, archery, horse racing, snow soccer ball, ecological hunting. Besides the local participants, it also attracts a number of foreign tourists. Meanwhile, the cultural and entertainment activities during the Nadamu are very colorful. Some troupes, Wulanmuqi troupes, film projection teams, and technology exhibitions sectors are gathered here to provide services for the pastoralists. It is also gathered with some commercial activities such as local snacks, Mongolia meals and goods exchanges. It is referred as Nomadic Olympic due to its colorful activities.

In recent years, the activities in Nadamu have had a rapid development and created some international brand. The First Ordos International Nadamu Festival was held in Ordos City, Inner Mongolia in August 2010. The delegation from nine countries participated in the competition events: bock, horse racing, archery, international style wrestling, Mongolian chess (that is, the first batch of national intangible cultural heritage), cars racing, motorcycle racing, tennis, basketball, and Shuttlecock. The programs included tug-of-war and human body Domino with ten thousand participants. Two Guinness World Records were created in the Nadam. The Second Ordos International Festival was scheduled to be held from August 27th through September 3 2012. There will be 16 programs with 112 items in total, including the newly added activities camel racing, shooting, Shuttlecock, Yajia, kites, Chinese-style wrestling, martial arts, outdoor tug-of-war, judo, cricket, hockey, etc.

We have made very promising achievements in Nadamu research in recent years. Combined with the Government publicity and protection policies on the intangible cultural heritage, many scholars have conducted theory and applied research on Nadamu. Some are conducted from the perspective of culture and sociology; some are conducted on the impact of activities on the regional economy and on the tourism industry. A multi-faceted research and fully exploration have been done with many achievements in master or doctoral thesis. It is worth mentioning that the Sports College of Inner Mongolia Normal University has had full-time Master's degree graduates from the major of Nationality Traditional Sports for three years. In recent years, under the joint efforts of the teachers and students, they have completed a series of research projects, including three national research projects and dozens of provincial projects. They have participated in international and domestic academic conferences for several times and published dozens of academic research papers in domestic core journals.

In short, under the environment of national cultural construction, the cultural development and innovative research will be conducted into depth continuously. With the strong support from the national policies and help, the national non-material cultural heritage such as Nadamu, Aobao Festival, Bock and Mongolian Chess, will have a better space for development, constantly adapt to the social development of the times, and add brilliant colors to the prosperity of China's traditional culture.

\section{REFERENCES}

[1] The Sports History of the People's Republic of China (local volume), China Book Press, 2002.12.

[2] Xiaokang Wei, Zheng Fang, Yanqing Zhang, Zhizhong Zhong. Research on Minority Traditional Sports Sustainable Development. Central University for Nationalities Publishing House, 2006-12.

[3] Yuan Rao, Zhu Liu. Chinese Minority Sports Culture General Theory, People's Publishing House, July 2009.

[4] Zhongjun, Yao. Minority Traditional Sports Culture Studies, Ethnic Publishing House, March 2004.

[5] Wa Gao. Status Quo and Strategies of Mongolian Traditional Sports and Cultural Development, 2005.10 Renmin University Books and News Information Center Reproduced.

[6] Xiaoying Li, The Development of the Modern Olympic Games and Traditional Mongolian Sports Development Strategies, The History of the Fourth Northeast Asia Sports Academic Conference Report,August 2001.

[7] Zhu Li, Jing Lai. Values of Chinese Traditional Sports Culture. Sports Culture Guide. 11th Issue, 2006.

[8] Xiaoying Li, Study on Development and Innovation of Traditional Mongolian Sports, Sports Culture Guide. March 2002. 